\title{
Bureaucratic corruption, environmental policy and inbound US FDI: theory and evidence
}

\author{
Per G. Fredriksson ${ }^{\mathrm{a}}$, John A. List ${ }^{\mathrm{b}}$, Daniel L. Millimet ${ }^{\mathrm{a}, *}$ \\ a Department of Economics, Southern Methodist University, P.O. Box 750496, Dallas, \\ TX 75275-0496, USA \\ ${ }^{\mathrm{b}}$ Department of Economics, University of Maryland, Baltimore, MD, USA
}

Received 11 January 2001; received in revised form 20 August 2001; accepted 19 December 2001

\begin{abstract}
Previous studies have proposed that equilibrium capital flows are affected by environmental regulations - the commonly coined 'pollution haven' hypothesis. We revisit this issue by treating environmental policies as endogenous and allowing governmental corruption to influence foreign direct investment patterns. Via these two simple extensions, we are able to provide a much richer model of international capital flows. The theoretical model presumes that the effect of corruption on FDI operates via two channels: corruption affects capital flows through its impact on environmental policy stringency and due to greater theft of public funds earmarked for public spending. We empirically examine the implications of the model using US state-level panel data from four industrial sectors over the period 1977-1987. Empirical results suggest environmental policy and corruption both play a significant role in determining the spatial allocation of inbound US FDI. In addition, the estimated effect of environmental policy is found to depend critically on exogeneity assumptions.
\end{abstract}

(C) 2003 Elsevier B.V. All rights reserved.

Keywords: Political economy; Corruption; Foreign direct investment; Firm location; Environmental regulations; Pollution haven

JEL classification: H00; L51; Q25; Q28; R1

\footnotetext{
*Corresponding author. Fax: +1-214-768-1821.

E-mail address: millimet@mail.smu.edu (D.L. Millimet).
} 


\section{Introduction}

Activities of multinational corporations have expanded considerably over the past 15 years. Data on worldwide nominal foreign direct investment (FDI) inflows show increases of nearly $18 \%$ per annum from 1985 to 1997 . This growth rate is stark in light of the much smaller rates of growth observed in GDP and trade flows. Perhaps even more surprising, in light of the political rhetoric associated with capital flight, is that industrialized economies received a major share $(71.5 \%)$ of these FDI inflows (Shatz and Venables, 2000). The asymmetric distribution of capital flows across countries has spurred a large literature examining the structural determinants of FDI flows (see, e.g. Froot, 1993). One insightful line of research includes studies that examine the effect of corruption on the cross-country pattern of FDI (Wheeler and Mody, 1992; Hines, 1995; Wei, 2000). A related line of work explores the impact of environmental regulation on US FDI, both inbound and outbound (see, e.g. Eskeland and Harrison, 1997; Keller and Levinson, 1999; List, 2001).

While the first set of studies suggests that corruption has a negative effect on FDI into developing countries, the latter group provides only weak evidence that lax environmental policies attract capital (i.e. that 'pollution havens' exist). This second set of studies, however, suffers from two potential deficiencies: (i) environmental policy is assumed exogenous, and (ii) governmental corruption is not explicitly modeled. ${ }^{1}$ At first glance, one may conclude that corruption in the US is minimal, and therefore should play little role in the (inbound) FDI decision. However, anecdotal evidence suggests otherwise. For instance, an environmentally-related corruption ring, termed Operation Silver Shovel by the FBI, was uncovered in the mid-1990s. In the end, corruption convictions were handed out to 18 Chicago residents: six were current or former city aldermen. Herbert Collins, former Special-Agent-in-Charge of the Chicago Field Division quipped: 'This investigation was initiated because of the concerns about public officials who were misusing their offices by permitting illegal landfills and other environmental misuses to occur.' ${ }^{2}$ The list of such distortions of environmental policy in the US is extensive, and highlights the need for a richer model of environmental policy determination.

In this paper, we attempt to remedy both potential deficiencies by investigating the impact of endogenous US state environmental regulations on FDI inflows, controlling for state level bureaucratic corruption. We therefore contribute to the literature on the pollution haven hypothesis as well as the relationship between corruption and FDI. To guide our empirical work, we first develop a simple theoretical model that endogenizes both environmental policy and the capital

\footnotetext{
${ }^{1}$ López and Mitra (2000) discuss the relationship between corruption, income, and pollution levels. They do not study environmental policy and capital flows, however.

${ }^{2}$ See http://www.fbi.gov/majcases/silvershovel/silvershovel.htm for further insights.
} 
stock. Our model makes use of results from the endogenous growth literature to provide insights into environmental policy regimes adopted by honest and corrupt bureaucrats. ${ }^{3}$ Worker and environmental lobby groups, in return for favorable environmental policies, offer the corrupt bureaucrats prospective bribes. ${ }^{4}$ Each corrupt bureaucrat is also assumed able to 'steal' a share of tax revenues that are earmarked for public expenditures.

According to the theoretical model, the influence of corruption on FDI operates via two distinct channels: the supply-side impact on the level of public goods provided, and the effect on environmental stringency. Presuming that foreign capital is attracted to locations with greater public funds, more widespread corruption reduces capital inflows through the theft of such funds. The model is inconclusive, however, with respect to the impact of corruption on environmental policy, although it does suggest that the effect of corruption on environmental stringency is contingent on the local tax effort. Finally, conditional on environmental regulation and public expenditures, corruption is assumed to have no measurable effect on FDI inflows.

We use state-level panel data from 1977 to 1987 to test the key aspects of the theoretical model. Our empirical examination, which makes use of two continuous measures of FDI-(i) gross value of plant, property, and equipment, and (ii) employment in foreign-owned affiliates for four groups: aggregate manufacturing, chemicals, metals, and food and kindred products-as well as discrete location choices across pollution and non-pollution intensive foreign-owned plants, validates several components of the theory. First, we find that corruption influences the supply of relevant public goods as well as the stringency of environmental regulations. Second, we find that public expenditures and the severity of environmental regulations influence FDI inflows in some sectors. Third, conditional on environmental policy and the supply of public goods, we find no remaining impact of corruption on capital inflows. Moreover, in accordance with our underlying premise, the empirical results are sensitive to the exogeneity assumption: whether we examine FDI flows or stocks, we find that the curious results in the received literature are partly explained by the statistical treatment of environmental regulations. Thus, our results not only lend support to our theory, but also are consonant with economic intuition.

The organization of the paper is as follows. Section 2 sets up a simple model of

\footnotetext{
${ }^{3}$ See, for example, Morrison and Schwartz (1996) and Chandra and Thompson (2000).

${ }^{4}$ Our menu auction model builds on Grossman and Helpman (1994), and extends Oates and Schwab (1988) and Fredriksson and Gaston (2000). See Damania (2001) for a recent application to environmental policy.

${ }^{5}$ There are also numerous instances of other forms of corruption, such as theft of public funds. The list of public corruption cases at the state level in the US includes extortion charges, racketeering and embezzlement indictments, state officials accepting bribes for lower taxes and easier access to permits, and fraudulent land deals. A laundry list of recent US political crimes can be found at: http:/ /www.constitution.org/uslaw/ corrupt.txt.
} 
bureaucratic corruption, environmental policy, and capital flows. Section 3 describes the empirical model and the data. Section 4 reports the results. Section 5 concludes.

\section{The model}

A small open jurisdiction (e.g. a US state) has a large number of workers, environmentalists, and bureaucrats. Bureaucrats are of two types: honest and dishonest (corrupt). The incidence of corruption among the $\beta^{B}$ bureaucrats is $\gamma \in[0,1]$, and the honest bureaucrats are a share $(1-\gamma)$. A state may also have capital owners residing within its borders. Normalizing the population to 1 , let $\beta^{W}$, $\beta^{E}, \beta^{H B}, \beta^{D B}$, and $\beta^{K}$ represent the proportion of the population that are workers, environmentalists, honest bureaucrats, dishonest bureaucrats, and capital owners, indexed $j=W, E, H B, D B, K$, respectively. All individuals gain utility from consuming the polluting good, but environmentalists also suffer disutility from pollution damage from local production. Individuals have additively separable utility functions $U^{j}=c^{j}-\lambda^{E} \Psi$, where $\lambda^{E}=1$ for environmentalists ( 0 otherwise), and $\Psi$ represents aggregate pollution damage.

Each jurisdiction has firms producing a private good, $Q$, for perfectly competitive national and international markets; price equals unity. Production requires inputs of capital, $K$, labor, $L$, where $L=\beta^{W}$, polluting waste emissions, $\Psi$, and a publicly provided good, $S$, that increases the productivity of capital and labor. The production technology exhibits constant returns to scale, is concave and increasing in all inputs, and twice continuously differentiable: $Q=F(K, L, \Psi, S)$, which can be rewritten as $Q=L f(k, \psi, s)$, where $k=K / L$ is the capital-labor ratio, $\psi=\Psi / L$, $\psi \in P, P \in \mathfrak{R}_{+}$is the emissions-labor ratio, and $s=S / L$ is the public good-labor ratio. Using subscripts to denote partial derivatives, the marginal products of capital, emissions, the public good, and labor are given by $f_{k}, f_{\psi}, f_{s}$, and $\left(f-k f_{k}-\psi f_{\psi}-s f_{s}\right)$, respectively, where $f_{k k}<0, f_{\psi \psi}<0, f_{s s}<0$. We assume $f_{k \psi}>$ $0, f_{k s}>0$, and $f_{s k}>0$. However, $f_{s \psi}=0$.

Each bureaucrat is responsible for administering both environmental policy and the local provision of the public good. Thus, each bureaucrat performs two tasks in our model, and is a 'representative bureaucrat.' The emissions-labor ratio, $\psi$, is the environmental policy set by the bureaucrats. Because the number of workers is fixed, $\psi$ determines aggregate emissions for each jurisdiction. The amount of the public good provided is determined by the amount of revenues raised by an exogenous capital tax $t$ levied on the capital stock located within the jurisdiction, and capital flows affect the provision of the public good. However, these funds are administered inefficiently: dishonest bureaucrats are assumed to steal the share of tax revenues that they oversee, and use it for personal consumption, such that $s=k t(1-\gamma)$. While labor is immobile, the global capital stock is perfectly mobile nationally and internationally, and investment flows respond instantaneously to 
changes in variables affecting the rate of return to capital (without associated adjustment costs), in particular environmental policy and the level of public good spending. The rate of return on capital, $r$, is consequently equalized across jurisdictions (Devereux and Freeman, 1995). Investors must take the capital tax into consideration, and therefore the equilibrium condition for the capital stock is given by

$$
f_{k}+f_{s} t(1-\gamma)-t=r
$$

An increase in the capital stock increases output directly by making more capital available per worker, and indirectly by increasing the level of the public good provided (given $t>0$ and $\gamma<1$ ). Differentiation of (1) provides the effect of the emissions policy on capital flows,

$$
\frac{\partial k}{\partial \psi}=-\frac{f_{k \psi}}{D}
$$

where $D \equiv f_{k k}+f_{s s} t^{2}(1-\gamma)^{2}+2 f_{k s} t(1-\gamma)$ and $f_{k s}=f_{s k}$ by Young's Theorem. Assuming decreasing marginal return to capital, it follows that $D<0$ and (2) is positive.

The income of environmentalists is exogenous. Each worker supplies one unit of labor and the wage equals the sum of the marginal product of labor plus the additional output arising from the increase in allowable emissions, $\psi f_{\psi}$. Hence, the wage rate is given by $w=f-k f_{k}-s f_{s}$.

Environmentalists and workers are assumed able to form separate lobby groups (see Olson, 1965). ${ }^{6}$ Assuming that capital owners are unable to coordinate simultaneous bribery in a major share of all small jurisdictions (e.g. all US states), which would affect the rate of return to capital, they have no incentive to bribe bureaucrats in any jurisdiction. They suffer free-riding problems because they can instead freely alter their spatial allocation of the capital stock to take advantage of rate of return differences across jurisdictions.

\footnotetext{
${ }^{6}$ In practice, there seems to be distinct sets of individuals within each group. For example, Kahn and Matsusaka (1997) report that workers involved with the manufacturing sector, and less educated people in general, were opposed to environmental initiatives in California, whereas highly educated urban dwellers were in favor.

${ }^{7}$ In this model any bribery-induced jurisdiction-specific reduction in the stringency of environmental policy simply results in a capital inflow, equalizing returns (see Gordon and Bovenberg (1996) for an alternative treatment). Bribery thus yields a negative return for capital owners. The fact that capital owners do not form a lobby group (and do not offer bribes) thus follows from the assumption of perfect capital mobility (in our view, US FDI appears relatively free to locate in any state) combined with free-riding problems. Durden et al. (1991) argue that mining sector employees had a strong impact on coal strip-mining control legislation, whereas environmentalists and the mining industry had below average impacts, with the latter group having the weakest effect overall. Alternatively, in a two-period model with imperfect information, a capital owner bribe-giver may recapture the bribe-investment if other investors are slow to discover the rate of return advantage available.
} 
The net (indirect) utility function of the worker lobby is given by:

$$
V^{W}(\psi) \equiv \beta^{W}\left(f-k f_{k}-s f_{s}\right)-C^{W}(\psi)
$$

and the aggregate net welfare of the environmental lobby group is:

$$
V^{E}(\psi) \equiv \beta^{E}\left(Y^{E}-\Psi\right)-C^{E}(\psi)
$$

where $C^{i}(\psi)$ is the policy-contingent bribe given by lobby $i$, and $Y^{E}$ denotes the environmentalists' per capita income. We assume that it is not criminal to offer a bribe. The dishonest bureaucrat derives utility from her salary, collected bribes, and stolen public funds:

$$
V^{D B}(\psi) \equiv Y^{B}+\sum_{i=W, E} C^{i}(\psi)+\frac{\beta^{W} k t \gamma}{\beta^{D B}}-\rho \varphi
$$

where $Y^{B}$ is each bureaucrat's exogenous salary, $\beta^{W} k t \gamma / \beta^{D B}$ represents the dishonest bureaucrat's personal income from theft of capital tax revenues, $\rho \in$ $[0,1]$ is the exogenous detection probability, and $\varphi>0$ represents the punishment associated with detection. ${ }^{8}$ Hereafter, for parsimony, we present most derivations in Appendix A.

A bureaucrat's job description is to maximize social welfare at the long run equilibrium level of the capital stock. Whereas honest bureaucrats closely follow their job description by setting the environmental standard at the welfare maximizing level, $\hat{\psi}$, dishonest bureaucrats deviate from $\hat{\psi}$ by choosing a policy $\tilde{\psi}^{9}$. Each bureaucrat has influence over one aspect of environmental policy, or at a particular stage of the process. We assume that the effective environmental policy faced by capital owners, denoted by $\psi^{\circ}$, is determined as a weighted average of the environmental policies favored by honest $(\hat{\psi})$ and dishonest $(\tilde{\psi})$ bureaucrats:

$$
\psi^{o}=\gamma \tilde{\psi}+(1-\gamma) \hat{\psi}
$$

The equilibrium emissions policy favored by a dishonest bureaucrat is determined as the outcome of a two-stage non-cooperative game. In stage one, the lobby groups offer the dishonest bureaucrats bribe schedules $C^{i}(\tilde{\psi}), i=W, E$. In stage two, each dishonest bureaucrat selects a policy and collects the associated bribe from the lobbies which are assumed not to renege on their promises. The number

\footnotetext{
${ }^{8}$ Our model abstracts from a number of issues related to corruption that, in our view, are of relatively minor importance for the analysis. For example, the assumption of $\rho<1$ is clearly a simplification in a full information model. In reality, there is some underlying process whereby corrupt bureaucrats and bribers match, and some other process whereby the bribe takers are detected (see, e.g. Basu et al., 1992 and Mookherjee and Png, 1995).

${ }^{9}$ For simplicity we do not present the implicit expression for $\hat{\psi}$. The size of $\hat{\psi}$ relative to $\tilde{\psi}$ is indeterminate due to the influence of two opposing lobby groups.
} 
of corrupt bureaucrats is assumed to be large, and no strategic interaction occurs-they operate in isolation from each other.

To examine the effect of corruption on capital flows, we differentiate (1), using (2), (6), and $\partial s / \partial \gamma=-t k$, which yields:

$$
\frac{\mathrm{d} k}{\mathrm{~d} \gamma}=\frac{\partial k}{\partial \psi^{o}} \frac{\partial \psi^{o}}{\partial \gamma}+\frac{\partial k}{\partial s} \frac{\partial s}{\partial \gamma}=-\underbrace{\frac{f_{k \psi}\left(\tilde{\psi}-\hat{\psi}+\gamma \frac{\partial \tilde{\psi}}{\partial \gamma}\right)}{D(+)}+\underbrace{\frac{f_{k s}}{f_{k k}} t k}_{(?)}}_{A}
$$

Eq. (7) shows two main channels through which corruption influences capital flows. First, corruption influences the level of the capital stock through its effect on environmental policy (term A). This effect is positive (negative) if an increase in the incidence of corruption results in weaker (stricter) environmental policy, in which case corruption results in a capital inflow (outflow). ${ }^{10}$ Second, corruption influences the amount of provided infrastructure (term B). This effect is unambiguously negative as an increase in stolen revenues reduces the amount spent on productivity enhancing public goods, thus lowering the productivity of capital.

\section{Empirical analysis}

In the empirical analysis, our goal is to test the claims of our theory and shed new light on the pollution haven hypothesis. Specifically, we: (i) analyze whether environmental standards and/or public expenditures are partly responsible for the observed spatial variation in FDI inflows across US states and (ii) examine the role corruption plays in the determination of environmental policy and public spending. Our baseline model, which is similar in spirit to Keller and Levinson (1999), amounts to a ten period linear fixed effects panel data model for the 48 contiguous states:

$$
F D I_{i t}=\alpha_{i}+\lambda_{t}+R_{i t} \delta_{0}+S_{i t} \delta_{1}+X_{i t} \beta+\varepsilon_{i t}
$$

where $F D I_{i t}$ is a continuous measure of inbound FDI for state $i$ at time $t, \alpha_{i}$ is a time-invariant state fixed effect, $\lambda_{t}$ is a location-invariant time fixed effect, $R_{i t}$ is a vector of covariates measuring state environmental stringency, $S_{i t}$ is a vector of covariates measuring the supply of relevant public goods, $X_{i t}$ is a vector of control variables, and $\varepsilon_{i t} \sim N\left(0, \sigma^{2}\right)$ is a well behaved error term. Vectors $\delta_{0}$ and $\delta_{1}$ contain the parameters of interest. The omission of corruption as a regressor in Eq. (8) is intentional. Taking the theoretical model literally, corruption has no effect on FDI

\footnotetext{
${ }^{10}$ If $\gamma \approx 0$, then $\partial \psi^{o} / \partial \gamma>(<) 0$ if $\tilde{\psi}>(<) \hat{\psi}$. If $\partial \tilde{\psi} / \partial \gamma>0$ and $\tilde{\psi}>\hat{\psi}$, then $\partial \psi^{o} / \partial \gamma>0$. Moreover, from (A.3), $\partial \tilde{\psi} / \partial \gamma$ depends on $\gamma$ (implying a non-linear relationship), and is conditional on $t$.
} 
conditional on environmental policy and the provision of public goods. In other words, corruption influences capital flows only via its effects on environmental policy and on the amount of publicly provided productivity enhancing goods (see Eq. (7)).

Our regressands are two continuous measures of FDI: (i) gross value of plant, property, and equipment (PP\&E) and (ii) employment in foreign-owned affiliates. We use data from four 'sectors': aggregate manufacturing, chemicals, metals, and food and kindred products. Our analysis begins with these stock data because they represent variables that politicians may often identify with prosperity. ${ }^{11}$ The reader is referred to Keller and Levinson (1999) for a detailed account of the data and various sources. We provide summary statistics in Table 1.

$R_{i t}$ includes Levinson's (2001) index of state environmental abatement costs as well as a quadratic term to allow for a possible non-linear effect of environmental stringency, consistent with our theory (see Eq. (A.3)). The index of environmental stringency, termed the Levinson Index hereafter, accounts for differences in state industrial composition and is defined as:

$$
E_{i t}^{*}=\frac{E_{i t}}{\hat{E}_{i t}}
$$

where $E_{i t}$ is the actual pollution abatement cost, $P A C E_{i t}$, per dollar of output, $Y_{i t}$, produced in state $i$ at time $t$ (i.e. $E_{i t}=P A C E_{i t} / Y_{i t}$ ). $\hat{E}_{i t}$ is the predicted pollution abatement cost per dollar of output and is given by:

$$
\hat{E}_{i t}=\frac{1}{Y_{i t}} \sum_{m=20}^{39}\left(\frac{Y_{i m t}}{Y_{m t}}\right) P A C E_{m t}
$$

where $m=20, \ldots, 39$ indexes the two-digit SIC manufacturing sectors, $Y_{i m t}$ is total output in state $i$ from sector $m$ at time $t, Y_{m t}$ is total national output (GDP) from sector $m$, and $P A C E_{m t}$ is total national pollution abatement costs spent by industries in sector $m$. Eq. (10) provides the average pollution abatement costs per dollar of state output that would exist in state $i$ at time $t$ if each firm conformed to the national average for its industry. Consequently, the index yields the ratio between actual pollution costs per dollar of output and predicted pollution costs per dollar of output. A value greater (less) than one indicates that industries in the state spend relatively more (less) per dollar of output on abatement than identical industries located in other states.

To measure the provision of public goods, $S_{i t}$ includes non-military government

\footnotetext{
${ }^{11}$ Our choice of dependent variables also maintains consistency with previous studies that examine the impact of environmental standards on inbound FDI (e.g. Keller and Levinson, 1999). Our choice is also consistent with studies that examine whether environmental regulations affect manufacturing activity (e.g. Henderson (1996) uses the stock of plants as his regressand; Greenstone (1998) uses employment, capital stock, and shipments).
} 
Table 1

Summary statistics $(1977-1986)^{a}$

\begin{tabular}{|c|c|c|c|c|}
\hline Variable & Observations & Mean (S.D.) & Min & Max \\
\hline Levinson Index & 480 & $1.02(0.40)$ & 0.23 & 2.59 \\
\hline Bureaucratic convictions & 465 & $0.03(0.04)$ & 0.00 & 0.33 \\
\hline PP\&E: Manufacturing & 475 & $1458.87(1901.00)$ & 12 & 14946 \\
\hline PP\&E: Chemicals & 376 & $741.29(1293.57)$ & 1 & 9893 \\
\hline PP\&E: Metals & 387 & $201.10(276.83)$ & 0 & 1633 \\
\hline PP\&E: Machinery & 374 & $186.40(273.02)$ & 0 & 2465 \\
\hline \multicolumn{5}{|l|}{ PP\&E: Food and kindred } \\
\hline Employment: Manufacturing & 478 & $24123.70(26326.48)$ & 50 & 150462 \\
\hline Employment: Chemicals & 384 & $7055.55(9041.30)$ & 61 & 53936 \\
\hline Employment: Metals & 435 & $3124.93(3350.34)$ & 0 & 22137 \\
\hline Employment: Machinery & 369 & $5877.00(7044.18)$ & 3 & 44563 \\
\hline \multicolumn{5}{|l|}{ Employment: Food and } \\
\hline kindred products & 456 & $2936.19(3434.41)$ & 10 & 18124 \\
\hline New plants: Manufacturing & 480 & $1.19(2.14)$ & 0 & 14 \\
\hline $\begin{array}{l}\text { New plants: Pollution- } \\
\text { intensive only }\end{array}$ & 480 & $0.61(1.18)$ & 0 & 8 \\
\hline Highway mileage (1000s) & 480 & $80.43(47.60)$ & 5.10 & 285.96 \\
\hline Market proximity & 480 & $4881.70(5751.44)$ & 290.95 & 41918.75 \\
\hline Tax effort & 480 & $95.34(17.69)$ & 59.50 & 171.00 \\
\hline Agric. land values & 480 & $793.58(510.04)$ & 90.78 & 2531.00 \\
\hline Industrial energy prices & 480 & $5.33(1.85)$ & 1.86 & 12.40 \\
\hline \multicolumn{5}{|l|}{ Ave. production hourly } \\
\hline wage & 480 & $7.80(1.75)$ & 4.10 & 12.80 \\
\hline Manufacturing GSP & 480 & 15842.69 (17 359.22) & 319.40 & 88626.80 \\
\hline Government GSP & 480 & $8783.96(9526.58)$ & 740.00 & 56485.10 \\
\hline Share of legal services & 480 & $0.01(0.00)$ & 0.01 & 0.02 \\
\hline $\begin{array}{l}\text { Per Capita GSP (1000s, } \\
1987 \text { US\$) }\end{array}$ & 480 & $15.93(2.55)$ & 11.24 & 26.04 \\
\hline
\end{tabular}

${ }^{\text {a }}$ Corruption rates correspond to the years 1978-1987. PP\&E = plant, property, and equipment and is measured in millions of US\$.

Gross State Product (GSP) and total highway mileage. While the theoretical model suggests that corruption has no impact on inbound FDI conditional on the supply of relevant public goods (and environmental policy), if our two measures only partially capture differences in the supply of public goods, then we may find a statistically significant effect of corruption on FDI nonetheless. Thus, as a robustness check, we estimate an expanded version of Eq. (8):

$$
F D I_{i t}=\alpha_{i}+\lambda_{t}+R_{i t} \delta_{0}+S_{i t} \delta_{1}+\delta_{2} C_{i t}+X_{i t} \beta+\varepsilon_{i t}
$$

where $C_{i t}$ is a measure of corruption and the other variables are defined above.

To measure bureaucratic corruption, we use the number of convictions of public officials per 1000 public employees. The data come from a 1987 US Department of Justice report, and have been used in Goel and Nelson (1998) and Fisman and 
Gatti (1999). The report provides state-level data on the number of public officials convicted annually of corruption-related activities from 1977 to 1987, although a few randomly missing observations exist. ${ }^{12}$ Finally, $X_{i t}$ includes all of the remaining control variables used in Keller and Levinson (1999): tax effort, unemployment and unionization rates, market proximity, population, industrial energy prices, agricultural land value, and the mean hourly wage of production workers.

According to the theory, the main econometric issue to be confronted in the empirical modeling is the endogeneity of environmental policy, $R$, and the provision of public goods, $S$. To account for potential endogeneity, we instrument for environmental policy and government GSP. ${ }^{13}$ Moreover, we utilize the panel aspect of our data and include both time and state fixed effects in (8) and (11). To our knowledge, this is the first empirical study to endogenize such determinants of FDI. For a successful application, the issue is to find appropriate instruments.

To instrument for environmental policy, besides the inclusion of corruption and its quadratic, we follow Fredriksson and Millimet (2000), who examine the effect of corruption on state environmental policy using similar data. Variables found to be key determinants of environmental policy and available as instruments in the present analysis include per capita state GSP and the share of legal services in GSP. Per capita GSP may affect environmental stringency to the extent that environmental quality is a normal good (Kahn and Matsusaka, 1997), as well as for other reasons alluded to in the environmental Kuznets curve literature. Expenditures on legal services may explain the differential enforcement of environmental legislation across states by affecting the resources devoted to enforcing regulations (or, conversely, protecting firms from enforcement) (e.g. Helland, 1998). For similar reasons, we also include non-military government employment and the interaction between non-military government employment and share of legal services in GSP as instruments, as relatively larger bureaucracies may expend more labor monitoring and enforcing regulations. We also include quadratic terms for per capita GSP, legal services, and government employment. Finally, to maintain consistency with our theory (Eq. (A.3)), we interact the corruption and tax effort variables.

We use the same set of instruments to control for the potential endogeneity of

\footnotetext{
${ }^{12}$ Clearly, this is not an ideal measure of corruption. First, convictions are only recorded if the corrupt bureaucrats are caught and evidence of their guilt is obtained. Second, the data treat all corruption convictions homogeneously. Third, we are only concerned with corruption levels in the state environmental bureaucracy; hence, we assume that the fraction of these levels devoted specifically to environmental protection is roughly uniform across states. Finally, the date of conviction provides no indication of when the corrupt activity actually occurred. We attempt to circumvent this final problem by using the number of convictions in year $t+1$ to proxy for corruption in year $t$. Despite these caveats, it remains the best available measure of corruption (Goel and Nelson, 1998).

${ }^{13}$ Since highway mileage changes more slowly and reflects past infrastructure investments, we treat it as exogenous.
} 
government GSP. One might expect government GSP to be positively related to government employment to the extent that Bureaucracy size is indicative of the role of the government in the economy. However, whereas public expenditure is determined annually through normal budgetary processes, employment reflects previous hiring decisions. Thus, we treat employment as exogenous. Per capita GSP may also be positively associated with government GSP if wealthier states generate greater tax revenue. Finally, since $s=t k(1-\gamma)$ in the theoretical model (and $\partial s / \partial \gamma=-t k$ ), corruption and its interaction with tax effort are also available instruments.

In Section 4, we present estimates based on instrumental variables estimation with fixed effects (IV-FE), and OLS with fixed effects (OLS-FE) for comparison. Since models treating environmental stringency and government GSP endogenously are over-identified, we provide results of Lagrange Multiplier (LM) tests for the validity of instruments. We also present Hausman test results, testing whether environmental policy and government GSP are exogenous.

As a further test of our theory, we also investigate the effect of environmental stringency and publicly provided capital on the number of discrete births of foreign-owned plants. ${ }^{14}$ Since the continuous measures of FDI discussed previously may reflect past choices of foreign firms, one may expect a priori new plant births to be more sensitive to changes in regulatory stringency and the provision of public goods. To estimate the count of new foreign-owned plants, we use a fixed effects negative binomial specification, where the fixed effects are defined at the year and Bureau of Economic Analysis (BEA) regional level. The use of regional-as opposed to state-fixed effects follows Keller and Levinson (1999), and results from the fact that there is insufficient variation at the state level to identify the model with state-specific effects. ${ }^{15}$ To provide a distinction between dirty and clean plants, we aggregate locating plants into two categories: (i) total manufacturing, and (ii) pollution-intensive industries. ${ }^{16}$

To treat environmental policy and government GSP as endogenous in the determination of location choice for new plants, we utilize a two-step procedure. First, we estimate the determinants of environmental stringency and government GSP using the instrument set listed above. We then include the predicted values of these variables in the second-stage negative binomial specifications. We obtain correct standard errors based on 1000 bootstrap repetitions.

\footnotetext{
${ }^{14}$ These data are taken from the International Trade Administration's (ITA) publication Foreign Direct Investment in the United States. Annually, the ITA summarizes information from publicly available sources, such as files from government agencies, to classify FDI according to: type of investment, 4-digit SIC code of the investment, the investing country, location of the investment, and in some cases, the total cost of the completed investment.

${ }^{15}$ Over $75 \%$ of the observations received either zero or one new foreign-owned plant.

${ }^{16}$ Following List and Co (2000), pollution-intensive industries are defined as SIC 26, 28, 29, 32, 33, 34 , and 37.
} 
Table 2

Determinants of inbound FDI by sector: IV-fixed effects (1977-1986)

\begin{tabular}{|c|c|c|c|c|c|c|c|c|c|c|c|c|c|c|c|c|}
\hline \multirow[t]{2}{*}{ Variable } & \multicolumn{4}{|c|}{ Plant, property and equipment } & \multicolumn{4}{|l|}{ Employment } & \multicolumn{4}{|c|}{ Plant, property and equipment } & \multicolumn{4}{|c|}{ Employment } \\
\hline & $\mathrm{I}$ & II & III & IV & $\mathrm{I}$ & II & III & IV & $\mathrm{I}$ & II & III & IV & $\mathrm{I}$ & II & III & IV \\
\hline & All manufa & acturing & & & & & & & Chemicals & & & & & & & \\
\hline Levinson index & $\begin{array}{r}706.39 \\
(0.97)\end{array}$ & $\begin{array}{r}-9207.43 \\
(-2.40)\end{array}$ & $\begin{array}{r}1076.19 \\
(1.26)\end{array}$ & $\begin{array}{r}-5848.21 \\
(-1.55)\end{array}$ & $\begin{array}{r}3543.47 \\
(0.56)\end{array}$ & $\begin{array}{r}-45465.15 \\
(-1.67)\end{array}$ & $\begin{array}{r}12372.82 \\
(1.52)\end{array}$ & $\begin{array}{r}-15111.84 \\
(-0.47)\end{array}$ & $\begin{array}{c}190.17 \\
(0.26)\end{array}$ & $\begin{array}{r}-8604.66 \\
(-2.38)\end{array}$ & $\begin{array}{c}-208.28 \\
(-0.24)\end{array}$ & $\begin{array}{r}-6838.61 \\
(-1.75)\end{array}$ & $\begin{array}{r}2242.99 \\
(0.71)\end{array}$ & $\begin{array}{r}-34913.02 \\
(-2.01)\end{array}$ & $\begin{array}{r}-1084.43 \\
(-0.30)\end{array}$ & $\begin{array}{r}-35760.54 \\
(-2.06)\end{array}$ \\
\hline$(\text { Levinson index })^{2}$ & & $\begin{array}{r}3795.12 \\
(2.70)\end{array}$ & & $\begin{array}{r}2549.97 \\
(1.91)\end{array}$ & & $\begin{array}{c}19010.95 \\
(1.87)\end{array}$ & & $\begin{array}{r}10234.95 \\
(0.89)\end{array}$ & & $\begin{array}{r}3155.27 \\
(2.52)\end{array}$ & & $\begin{array}{r}2308.91 \\
(1.75)\end{array}$ & & $\begin{array}{c}14304.23 \\
(2.23)\end{array}$ & & $\begin{array}{r}13339.55 \\
(2.09)\end{array}$ \\
\hline Gov't GSP & $\begin{array}{c}0.36 \\
(3.44)\end{array}$ & $\begin{array}{c}0.20 \\
(1.18)\end{array}$ & $\begin{array}{c}0.41 \\
(3.75)\end{array}$ & $\begin{array}{c}0.30 \\
(1.99)\end{array}$ & $\begin{array}{l}-0.01 \\
(-0.02)\end{array}$ & $\begin{array}{l}-0.74 \\
(-0.63)\end{array}$ & $\begin{array}{c}0.73 \\
(0.70)\end{array}$ & $\begin{array}{c}0.29 \\
(0.24)\end{array}$ & $\begin{array}{c}0.38 \\
(3.35)\end{array}$ & $\begin{array}{c}0.21 \\
(1.30)\end{array}$ & $\begin{array}{c}0.39 \\
(3.17)\end{array}$ & $\begin{array}{c}0.28 \\
(1.85)\end{array}$ & $\begin{array}{l}-1.07 \\
(-2.42)\end{array}$ & $\begin{array}{l}-1.77 \\
(-2.42)\end{array}$ & $\begin{array}{l}-1.05 \\
(-2.39)\end{array}$ & $\begin{array}{l}-1.69 \\
(-2.48)\end{array}$ \\
\hline Highway miles & $\begin{array}{c}2.20 \\
(2.97)\end{array}$ & $\begin{array}{c}3.18 \\
(2.61)\end{array}$ & $\begin{array}{l}2.00 \\
(2.56)\end{array}$ & $\begin{array}{c}2.74 \\
(2.61)\end{array}$ & $\begin{array}{l}10.88 \\
(1.69)\end{array}$ & $\begin{array}{l}16.04 \\
(1.92)\end{array}$ & $\begin{array}{l}7.17 \\
(0.97)\end{array}$ & $\begin{array}{l}10.30 \\
(1.20)\end{array}$ & $\begin{array}{c}3.42 \\
(2.81)\end{array}$ & $\begin{array}{c}5.69 \\
(3.21)\end{array}$ & $\begin{array}{c}3.04 \\
(2.24)\end{array}$ & $\begin{array}{l}4.47 \\
(2.57)\end{array}$ & $\begin{array}{c}3.70 \\
(1.18)\end{array}$ & $\begin{array}{c}8.51 \\
(1.65)\end{array}$ & $\begin{array}{c}4.32 \\
(1.40)\end{array}$ & $\begin{array}{c}8.75 \\
(1.83)\end{array}$ \\
\hline Corruption & & & $\begin{array}{c}0.09 \\
(0.11)\end{array}$ & $\begin{array}{c}0.34 \\
(0.32)\end{array}$ & & & $\begin{array}{l}5.65 \\
(0.71)\end{array}$ & $\begin{array}{c}6.58 \\
(0.77)\end{array}$ & & & $\begin{array}{l}-0.50 \\
(-0.55)\end{array}$ & $\begin{array}{c}0.17 \\
(0.15)\end{array}$ & & & $\begin{array}{c}2.01 \\
(0.52)\end{array}$ & $\begin{array}{c}3.50 \\
(0.64)\end{array}$ \\
\hline 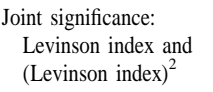 & & $P=0.02$ & & $P=0.10$ & & $P=0.16$ & & $P=0.25$ & & $P=0.04$ & & $P=0.21$ & & $P=0.08$ & & $P=0.11$ \\
\hline $\begin{array}{l}\text { Joint significance: } \\
\text { Gov't GSP and } \\
\text { highway miles }\end{array}$ & $P=0.00$ & $P=0.00$ & $P=0.00$ & $P=0.00$ & $P=0.22$ & $P=0.16$ & $P=0.37$ & $P=0.35$ & $P=0.00$ & $P=0.00$ & $P=0.00$ & $P=0.00$ & $P=0.05$ & $P=0.04$ & $P=0.04$ & $P=0.03$ \\
\hline $\begin{array}{l}\text { Estimated peak/trough: } \\
\text { Levinson index }\end{array}$ & & $\begin{array}{c}1.21 \\
{[0.15]}\end{array}$ & & $\begin{array}{c}1.15 \\
{[0.24]}\end{array}$ & & $\begin{array}{c}1.20 \\
{[0.21]}\end{array}$ & & $\begin{array}{c}0.74 \\
{[0.80]}\end{array}$ & & $\begin{array}{c}1.36 \\
{[0.14]}\end{array}$ & & $\begin{array}{c}1.48 \\
{[0.22]}\end{array}$ & & $\begin{array}{c}1.22 \\
{[0.17]}\end{array}$ & & $\begin{array}{c}1.34 \\
{[0.19]}\end{array}$ \\
\hline$R^{2}$ & 0.94 & 0.85 & 0.93 & 0.90 & 0.97 & 0.96 & 0.97 & 0.96 & 0.89 & 0.82 & 0.88 & 0.85 & 0.95 & 0.89 & 0.95 & 0.91 \\
\hline LM t & $P=0.00$ & $P=0.77$ & $P=0.13$ & $P=0.88$ & $P=0.00$ & $P=0.05$ & $P=0.12$ & $P=0.15$ & $P=0.00$ & $P=0.14$ & $P=0.01$ & $P=0.12$ & $P=0.00$ & $P=0.27$ & $P=0.00$ & $P=0.14$ \\
\hline Hausman test & $P=0.00$ & $P=0.00$ & $P=0.05$ & $P=0.02$ & $P=0.01$ & $P=0.00$ & $P=0.05$ & $P=0.09$ & $P=0.00$ & $P=0.00$ & $P=0.51$ & $P=0.21$ & $P=0.11$ & $P=0.01$ & $P=0.99$ & $P=0.06$ \\
\hline
\end{tabular}




\begin{tabular}{|c|c|c|c|c|c|c|c|c|c|c|c|c|c|c|c|c|}
\hline & Metals & & & & & & & & Food and & kindred pro & oducts & & & & & \\
\hline Levinson index & $\begin{array}{c}-328.04 \\
(-1.54)\end{array}$ & $\begin{array}{r}-942.38 \\
(-1.42)\end{array}$ & $\begin{array}{r}-230.54 \\
(-1.02)\end{array}$ & $\begin{array}{r}-275.25 \\
(-0.33)\end{array}$ & $\begin{array}{c}-3541.26 \\
(-1.41)\end{array}$ & $\begin{array}{r}-17583.38 \\
(-2.14)\end{array}$ & $\begin{array}{r}-3731.64 \\
(-1.31)\end{array}$ & $\begin{array}{r}-20506.52 \\
(-1.97)\end{array}$ & $\begin{array}{c}194.05 \\
(2.70)\end{array}$ & $\begin{array}{r}476.86 \\
(1.87)\end{array}$ & $\begin{array}{c}300.82 \\
(3.00)\end{array}$ & $\begin{array}{r}1471.88 \\
(2.39)\end{array}$ & $\begin{array}{r}3321.09 \\
\quad(2.17)\end{array}$ & $\begin{array}{c}-19.32 \\
(-0.00)\end{array}$ & $\begin{array}{c}5032.72 \\
(2.44)\end{array}$ & $\begin{array}{r}13982.80 \\
(1.27)\end{array}$ \\
\hline$(\text { Levinson index) })^{2}$ & & $\begin{array}{c}268.94 \\
(0.97)\end{array}$ & & $\begin{array}{l}18.08 \\
(0.06)\end{array}$ & & $\begin{array}{r}5169.34 \\
(1.81)\end{array}$ & & $\begin{array}{r}5833.76 \\
(1.70)\end{array}$ & & $\begin{array}{r}-101.55 \\
(-1.16)\end{array}$ & & $\begin{array}{c}-392.87 \\
(-1.96)\end{array}$ & & $\begin{array}{c}1091.81 \\
(0.57)\end{array}$ & & $\begin{array}{r}-2812.66 \\
(-0.84)\end{array}$ \\
\hline Gov't GSP & $\begin{array}{l}-0.03 \\
(-0.85)\end{array}$ & $\begin{array}{l}-0.03 \\
(-0.97)\end{array}$ & $\begin{array}{l}-0.01 \\
(-0.48)\end{array}$ & $\begin{array}{l}-0.01 \\
(-0.48)\end{array}$ & $\begin{array}{c}0.09 \\
(0.30)\end{array}$ & $\begin{array}{l}-0.21 \\
(-0.60)\end{array}$ & $\begin{array}{c}0.19 \\
(0.65)\end{array}$ & $\begin{array}{l}-0.12 \\
(-0.32)\end{array}$ & $\begin{array}{l}-0.01 \\
(-0.52)\end{array}$ & $\begin{array}{c}0.00 \\
(0.17)\end{array}$ & $\begin{array}{c}0.00 \\
(-0.26)\end{array}$ & $\begin{array}{c}0.03 \\
(1.06)\end{array}$ & $\begin{array}{c}0.30 \\
(1.65)\end{array}$ & $\begin{array}{c}0.28 \\
(1.48)\end{array}$ & $\begin{array}{c}0.43 \\
(1.81)\end{array}$ & $\begin{array}{c}0.49 \\
(1.73)\end{array}$ \\
\hline Highway miles & $\begin{array}{l}0.99 \\
(2.72)\end{array}$ & $\begin{array}{c}0.75 \\
(1.77)\end{array}$ & $\begin{array}{l}0.85 \\
(2.29)\end{array}$ & $\begin{array}{c}0.84 \\
(1.97)\end{array}$ & $\begin{array}{c}4.90 \\
(2.22)\end{array}$ & $\begin{array}{c}8.01 \\
(2.72)\end{array}$ & $\begin{array}{l}4.65 \\
(2.08)\end{array}$ & $\begin{array}{l}8.16 \\
(2.47)\end{array}$ & $\begin{array}{c}0.07 \\
(0.64)\end{array}$ & $\begin{array}{l}-0.08 \\
(-0.48)\end{array}$ & $\begin{array}{c}0.13 \\
(0.98)\end{array}$ & $\begin{array}{l}-0.39 \\
(-1.17)\end{array}$ & $\begin{array}{l}-0.91 \\
(-0.63)\end{array}$ & $\begin{array}{l}-0.69 \\
(-0.46)\end{array}$ & $\begin{array}{l}-1.64 \\
(-0.89)\end{array}$ & $\begin{array}{l}-2.30 \\
(-1.01)\end{array}$ \\
\hline Corruption & & & $\begin{array}{c}0.08 \\
(0.31)\end{array}$ & $\begin{array}{c}0.09 \\
(0.30)\end{array}$ & & & $\begin{array}{l}1.44 \\
(0.49)\end{array}$ & $\begin{array}{l}2.98 \\
(0.85)\end{array}$ & & & $\begin{array}{l}-0.04 \\
(-0.32)\end{array}$ & $\begin{array}{l}-0.12 \\
(-0.55)\end{array}$ & & & $\begin{array}{l}-0.69 \\
(-0.33)\end{array}$ & $\begin{array}{l}-1.51 \\
(-0.58)\end{array}$ \\
\hline $\begin{array}{l}\text { Joint significance: } \\
\text { Levinson index and } \\
\left(\text { Levinson index) }{ }^{2}\right.\end{array}$ & & $P=0.18$ & & $P=0.60$ & & $P=0.09$ & & $P=0.13$ & & $P=0.02$ & & $P=0.02$ & & $P=0.08$ & & $P=0.08$ \\
\hline $\begin{array}{l}\text { Joint significance: } \\
\text { Gov't GSP and } \\
\text { highway miles }\end{array}$ & $P=0.03$ & $P=0.17$ & $P=0.07$ & $P=0.14$ & $P=0.06$ & $P=0.02$ & $P=0.05$ & $P=0.03$ & $P=0.76$ & $P=0.89$ & $P=0.62$ & $P=0.46$ & $P=0.25$ & $P=0.34$ & $P=0.18$ & $P=0.21$ \\
\hline $\begin{array}{l}\text { Estimated peak/trough: } \\
\text { Levinson index }\end{array}$ & & $\begin{array}{c}1.75 \\
{[0.74]}\end{array}$ & & $\begin{array}{c}7.61 \\
{[115.28]}\end{array}$ & & $\begin{array}{c}1.70 \\
{[0.30]}\end{array}$ & & $\begin{array}{c}1.76 \\
{[0.34]}\end{array}$ & & $\begin{array}{c}2.35 \\
{[0.90]}\end{array}$ & & $\begin{array}{c}1.87 \\
{[0.28]}\end{array}$ & & $\begin{array}{c}0.01 \\
{[2.77]}\end{array}$ & & $\begin{array}{c}2.49 \\
{[1.15]}\end{array}$ \\
\hline $\begin{array}{l}R^{2} \\
\text { LM test }\end{array}$ & $\begin{array}{r}0.80 \\
=0.07\end{array}$ & $\begin{array}{r}0.81 \\
=0.05\end{array}$ & 0.81 & $\begin{array}{r} \\
0.82 \\
=0.08\end{array}$ & 0.87 & 0.84 & 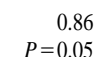 & 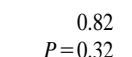 & $\begin{array}{r}0.90 \\
=0.00\end{array}$ & $\begin{aligned} & 0.90 \\
= & 0.00\end{aligned}$ & $\begin{array}{r} \\
0.85 \\
=0.00\end{array}$ & $\begin{array}{l}0.64 \\
=0.33\end{array}$ & $\begin{array}{r}0.94 \\
=0.00\end{array}$ & 0.94 & $\begin{array}{r}0.91 \\
P=0.59\end{array}$ & $\begin{array}{r}0.88 \\
P=0.75\end{array}$ \\
\hline Hausman test & $\begin{array}{l}P=0.07 \\
P=0.96\end{array}$ & $\begin{array}{l}P=0.05 \\
P=0.97\end{array}$ & $P=0.16$ & $\begin{array}{l}P=0.08 \\
P=0.38\end{array}$ & $P=0.71$ & $P=0.47$ & $P=0.33$ & $P=0.10$ & $P=0.00$ & $\begin{array}{l}P=0.00 \\
P=0.00\end{array}$ & $\begin{array}{l}P=0.00 \\
P=0.00\end{array}$ & $P=0.00$ & $\begin{array}{l}P-0.00 \\
P=0.15\end{array}$ & $P=0.16$ & $P=0.00$ & $P=0.00$ \\
\hline
\end{tabular}




\section{Empirical results}

The IV-FE empirical results based on the two continuous measures of FDI are presented by sector in Table 2. ${ }^{17}$ For each sector and FDI measure, Table 2 contains the estimates from four specifications. Model I is identical to the basic model in Keller and Levinson (1999) except for two changes. First, the model is estimated using data from 1977 to 1986 since this is the period of overlap with our measure of corruption. Second, the model includes non-military government GSP to control for the provision of public goods. Model II is identical to model I, but allows the effect of environmental stringency to be non-linear, as in Eq. (8). Model III (model IV) is identical to model I (model II) with the addition of our corruption measure, as in Eq. (11).

Before proceeding to the main results, we note that the first stage regression estimates are displayed in Appendix B (Table B1). As a robustness check, we provide estimates from models including (columns 1 and 3 ) and excluding (columns 2 and 4) corruption as an instrument. Of first note is that regardless of this choice, each specification is significant at the $P<0.001$ level, suggesting our equations have significant explanatory power. In terms of our theoretical predictions, corruption is an important determinant of both the Levinson Index and government GSP, and the effect is conditional on the level of tax effort. Moreover, the relationship between corruption and the Levinson Index is non-linear, becoming monotonically negative as tax effort increases. For the government GSP specification, also consonant with our theory, an increase in corruption levels unambiguously decreases government GSP (fixing tax effort at its mean value). Results in Table B1 provide evidence in favor of the underlying instrumenting equations. $^{18}$

Moving to the estimation results for Eqs. (8) and (11), we split our findings into three categories. First, consonant with the theoretical model, we find a positive and statistically significant effect of government GSP and highway infrastructure on inbound FDI flows in many sectors. Moreover, we note that in all of the specifications including corruption, the point estimate is not statistically different from zero at conventional levels. To the extent that government GSP and highway mileage are sufficient proxies for productive public capital, this finding is consistent with the theoretical model.

Second, we reject exogeneity of environmental policy and government GSP, and find that our instruments are valid in a majority of specifications. Finally, we find that the impact of environmental policy on FDI is quite sensitive to the exogeneity

\footnotetext{
${ }^{17}$ While the OLS-FE results are not reported to conserve space, the full set of results is posted at http://faculty.smu.edu/millinetpapers/fdiresults.pdf and many of the results are summarized in Fig. 1.

${ }^{18}$ Tests of the joint significance of the instruments for the Levinson Index and government GSP models yield $P$ values of $0.16,0.08,0.0001$, and 0.0001 , providing additional support in favor of our approach.
} 
assumption: the effect is generally insignificant if environmental policy is treated as exogenous, whereas the coefficients tend to be statistically significant in the IV-FE models. One potential explanation for this finding is that states compensate firms for the imposition of stringent environmental regulations, thus biasing estimates in models treating environmental policy as exogenous. Furthermore, the effect of environmental policy, when significant, tends to be non-linear. Thus, in the remaining discussion, we focus on our preferred specification (model II).

\subsection{Overall manufacturing}

The IV-FE results for the entire manufacturing sector are shown in Table 2, and both the IV-FE and OLS-FE results from the preferred model (model II) are summarized in Fig. 1. The OLS-FE results indicate a significant U-shaped pattern; despite the fact that the coefficients are individually never significant at the $5 \%$ level, they are jointly significant $(P=0.03)$. The trough occurs at a value of the Levinson Index around unity, implying that roughly $45 \%$ of states are on the upward sloping portion. When FDI is measured by employment, however, the OLS-FE results indicate no statistically significant effect of environmental stringency. In terms of public goods, consonant with our theory, highway mileage has a significant and positive effect on FDI, while government GSP has a significant, positive impact on FDI only when FDI is measured by PP\&E.

Turning to the IV-FE results, we find that our instruments pass the LM test for validity and we reject exogeneity at conventional levels for PP\&E, but not employment (see the final two rows in Table 2). In terms of the point estimates, however, treating environmental policy and government GSP endogenously has only a modest effect. Specifically, using PP\&E to measure FDI, we continue to find evidence of a U-shaped relationship between FDI and environmental stringency, and a significant and positive effect of highway infrastructure on FDI. The trough does occur at a higher value of the Levinson Index using the IV-FE results (approximately 1.21), implying that one-third of states lie on the upward sloping portion of the curve. Thus, even according to the IV-FE results, the non-linear relationship is not simply due to the presence of a few outliers. We believe this to mark a new empirical finding. ${ }^{19}$

When employment is used to measure FDI, the validity of the instruments is rejected at the 5\% level. Despite this, the IV-FE estimates differ little from the

\footnotetext{
${ }^{19}$ At first glance, the significant, non-linear relationship between FDI and environmental policy is puzzling. One possible explanation for the U-shape is related to the findings in Eliste and Fredriksson (2001). The authors present theoretical and empirical evidence suggesting that countries with strict environmental policies compensate polluters with subsidies. Similarly, US states with relatively strict regulations may seek to attract FDI by compensating firms through various transfer schemes. Our results suggest that in many cases foreign firms may be overcompensated. Note that even if our measure of tax effort incorporates current corporate tax breaks, the promise of future tax relief, as well as other transfers, may drive the upward-sloping portion of the $\mathrm{U}$.
} 


\begin{tabular}{|c|c|c|c|c|c|}
\hline \multirow[t]{2}{*}{ Sector } & \multirow[t]{2}{*}{ Variable } & \multicolumn{2}{|c|}{ PP\&E } & \multicolumn{2}{|c|}{ Employment } \\
\hline & & OLS-FE & IV-FE & OLS-FE & IV-FE \\
\hline \multirow{4}{*}{ 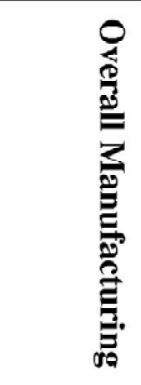 } & $\begin{array}{l}\text { Levinson } \\
\text { Index }\end{array}$ & - & $-* *$ & - & $-*$ \\
\hline & $\begin{array}{l}\text { Levinson } \\
\text { Index } \\
\text { Squared }\end{array}$ & $+^{*}$ & $+* *$ & + & $+^{*}$ \\
\hline & $\begin{array}{r}\text { Gov't } \\
\text { GSP }\end{array}$ & $+* *$ & + & + & - \\
\hline & $\begin{array}{c}\text { Highway } \\
\text { Mileage }\end{array}$ & $+* *$ & $+* *$ & $+* *$ & $t^{*}$ \\
\hline \multirow{4}{*}{ 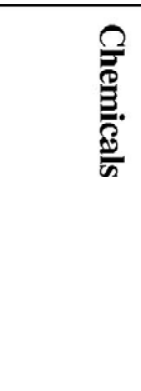 } & $\begin{array}{l}\text { Levinson } \\
\text { Index }\end{array}$ & - & $-* *$ & - & $-* *$ \\
\hline & $\begin{array}{l}\text { Levinson } \\
\text { Index } \\
\text { Squared }\end{array}$ & + & $+* *$ & + & $+* *$ \\
\hline & $\begin{array}{r}\text { Gov't } \\
\text { GSP }\end{array}$ & $+* *$ & + & $-* *$ & $-* *$ \\
\hline & $\begin{array}{r}\text { Highway } \\
\text { Mileage }\end{array}$ & $+* *$ & $+* *$ & $t^{*}$ & $+^{*}$ \\
\hline \multirow{4}{*}{$\frac{3}{\frac{a}{2}}$} & $\begin{array}{l}\text { Levinson } \\
\text { Index }\end{array}$ & - & - & - & $-* *$ \\
\hline & $\begin{array}{l}\text { Levinson } \\
\text { Index } \\
\text { Squared }\end{array}$ & + & + & + & + \\
\hline & $\begin{array}{l}\text { Gov't } \\
\text { GSP }\end{array}$ & - & - & + & - \\
\hline & $\begin{array}{r}\text { Highway } \\
\text { Mileage }\end{array}$ & $+* *$ & $t^{*}$ & $+* *$ & $+* *$ \\
\hline \multirow{4}{*}{ 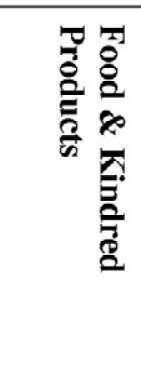 } & $\begin{array}{l}\text { Levinson } \\
\text { Index }\end{array}$ & + & $t^{*}$ & + & - \\
\hline & $\begin{array}{l}\text { Levinson } \\
\text { Index } \\
\text { Squared }\end{array}$ & - & - & - & + \\
\hline & $\begin{array}{r}\text { Gov't } \\
\text { GSP }\end{array}$ & + & + & + & + \\
\hline & $\begin{array}{r}\text { Highway } \\
\text { Mileage }\end{array}$ & - & - & + & - \\
\hline
\end{tabular}

Fig. 1. Summary of empirical results by sector: model II. Notes: See Table 2. $+/-$ represents the sign of the coefficient. * indicates significant at $10 \%$ level; ** indicates significant at $5 \%$ level. Results in shaded regions indicate that the instrument set passed the LM test of validity and the Hausman test rejected the null of exogeneity (both at the $5 \%$ level). 
OLS-FE results: environmental policy and government GSP have no effect on inbound total manufacturing FDI, and highway mileage has a modest, positive impact. Finally, concerning the other control variables, while the results are not shown, we note that population, market proximity, and tax effort have significant, positive effects on FDI in many of the specifications, while unionization rates and agricultural land values exert a significant, negative impact.

While the effects of environmental regulation and publicly provided capital are statistically significant, it is worthwhile to ask if the results are economically significant. To shed light on this issue, we consider a state, such as New York, that is located on the downward sloping portion of the U-shaped FDI-regulation relationship. In 1984, New York had a Levinson Index value of 0.65. According to the PP\&E results from model II, a one standard deviation increase in relative environmental stringency (an increase to 1.05) would have lowered total manufacturing PP\&E by nearly $30 \%$, from roughly $\$ 3700$ million to $\$ 2600$ million. According to the same model, a similar one standard deviation increase in government GSP (highway infrastructure) would lead to approximately a $51 \%$ (4\%) increase in total manufacturing PP\&E, from \$3700 million to \$5600 (\$3850) million. Thus, besides achieving statistical significance, these variables appear to be economically significant as well.

\subsection{Sector-specific results}

Table 2 also contains the IV-FE results for the chemicals, metals, and food and kindred products industries. Restricting attention to the preferred specification (model II), the success of the model varies across the sectors. For the chemicals sector, the model fairs extremely well: using either PP\&E or employment to measure FDI, we fail to reject the validity of our instruments and we reject exogeneity. Alternatively, for the metals industry, either the instruments are found to be invalid (PP\&E) or the instruments are found to be valid, but we fail to reject exogeneity (employment). Finally, for the food and kindred products sector, our instruments are never found to be valid.

Beginning with the point estimates from the chemicals sector, we find that the results are in accord with our theoretical predictions and the results for overall manufacturing. First, both the OLS-FE and IV-FE estimates yield a statistically significant U-shaped pattern between FDI flows (measured by PP\&E) and environmental policy (as before, for the OLS-FE estimates, the coefficients are jointly significant despite being individually insignificant). However, the OLS-FE model suggests that a vast majority of states are on the upward portion of the curve (trough occurs at 0.50), whereas the IV-FE results suggest that most states are on the downward portion of the curve (trough at 1.36). The latter finding indicates an inverse relationship between regulatory stringency and FDI inflows. Other coefficients are similar across the models and imply that government GSP and highway infrastructure are positively related to FDI inflows. 
Empirical results using employment to measure inbound FDI are even more striking. While the OLS-FE estimates suggest there is no impact of environmental regulations, the IV-FE results suggest that these estimates are biased. When these variables are treated endogenously, we find a statistically significant U-shaped relationship between inbound FDI and environmental stringency (with a trough of 1.22 , implying roughly $80 \%$ of states are on the downward sloping portion), as well as a significant positive effect of highway infrastructure. Government GSP, however, has a significant negative effect on FDI in both the OLS-FE and IV-FE results.

To illustrate the economic significance of these results, consider the example of California, which had a Levinson Index of roughly 0.8 in 1984. Our estimates predict that an increase in this figure by one standard deviation (to 1.2) reduces employment by over 2500 jobs, or about $6 \%$ of foreign affiliates' employment in the chemicals sector.

For the remaining two sectors-metals and food and kindred products- the empirical results are less informative. For the metals sector, the instruments are not found to be valid in the preferred specification (model II) when PP\&E is the dependent variable. While the instruments are valid using employment to measure FDI flows, the Hausman test fails to reject exogeneity. Moreover, the more efficient OLS-FE results find a statistically significant positive effect of highway mileage, but no impact of government GSP or environmental policy. For food and kindred products, regardless of choice of dependent variable, the LM test rejects instrument validity. Consequently, the OLS-FE results, while not finding any statistically significant effects, should be viewed with caution.

\subsection{New plants}

To further examine the determinants of inbound FDI, we analyze plant-level new firm location data, which may have a more fluid relationship with our variables of interest. The results from the negative binomial specifications examining the location choices of new foreign plants are summarized in Table 3, and are quite striking. ${ }^{20}$ In the specifications treating the Levinson Index and government GSP exogenously, we find a statistically significant, negative effect of environmental stringency, and a positive and significant effect of highway infrastructure on new plant births in manufacturing as a whole. Government GSP is positive, but insignificant. However, if we focus only on industries considered pollution-intensive, the effect of environmental stringency, while still negative, is no longer statistically significant. This finding is consistent with Keller and Levinson (1999), and is robust to inclusion of our corruption measure.

Once we control for the potential endogeneity of environmental regulations and

\footnotetext{
${ }^{20}$ In these specifications we simply include a linear measure of our variable of interest. Qualititative results are robust to inclusion of higher-order terms.
} 
Table 3

Determinants of new foreign-owned plants (1977-1986)

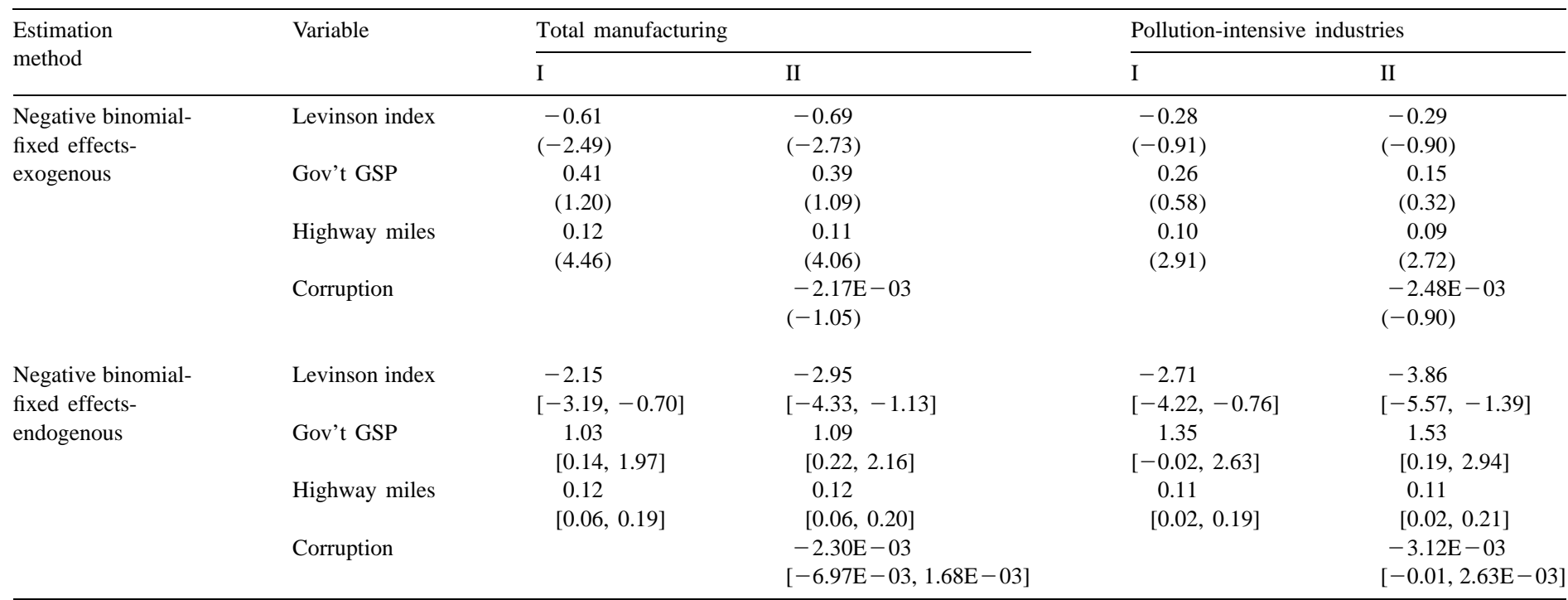

Notes: All regressions include regional and time fixed effects. Corruption is measured as the number of convictions one-year ahead per 1000 non-military government employees. 'Exogenous' implies that the actual values of the Levinson index and government GSP are included in the models. 'Endogenous' implies that the estimates are obtained via two-step estimation, where the predicted values of the Levinson index and government GSP are included in the models. Instrument set includes: corruption (measured as the absolute number of convictions one-year ahead) and corruption squared (model I only), corruption and corruption squared interacted with tax effort (model I only), legal services as a share of GSP, non-military government employment, per capita GSP, quadratic terms for each, and the interaction between non-military government employment and legal services as a share of GSP. Government GSP and highway miles measured in 10 000s. Control variables include: population, market proximity, unemployment and unionization rates, agricultural land value, industrial energy prices, tax effort, and mean hourly wage of production workers; $t$-statistics in parentheses; $95 \%$ confidence intervals obtained via 1000 bootstrap repetitions in brackets. 
government GSP, this puzzling result disappears. Replacing the actual values of these variables with predicted values-and obtaining corrected 95\% confidence intervals based on 1000 bootstrap repetitions-yields a negative and statistically significant effect of environmental stringency on foreign-owned new plant births both in manufacturing as a whole, as well as in the pollution-intensive subsample. Moreover, the effect is larger in magnitude in pollution-intensive industries, as the point estimates are approximately $40 \%$ larger in absolute value. Furthermore, while the effect of highway infrastructure continues to be positive and statistically significant, government GSP now has a significant beneficial impact on new plant births, as suggested by our theory. Finally, inclusion of corruption does not alter these findings. Thus, when endogeneity of the key variables is addressed, the surprising findings documented in the literature are avoided, and results consonant with our theory and economic intuition are obtained.

\section{Conclusion}

While the days of William 'Boss' Tweed, the infamous corrupt official from New York City, may be long gone from political circles in the US, that does not imply corruption fails to influence local public policies. In this paper, we make a new attempt at identifying 'pollution haven' effects by allowing corruption to indirectly affect FDI flows. We conjecture that the influence of corruption on FDI evolves via two channels: the impact on the supply of public goods and the effect on environmental stringency. The model suggests that more widespread theft of public funds (due to a greater incidence of corruption) reduces capital inflows, while corruption also influences capital inflows through its ambiguous effect on environmental policy.

We use state-level panel data from 1977 to 1987 to test the main aspects of the theory. In many respects, the data provide a nice external validation of the model - whether we examine stocks or flows, our results suggest that environmental policy stringency and corruption play a significant role in shaping the spatial allocation of foreign investment into the US. We also find that certain modeling assumptions are critically important-measured effects of environmental policy stringency on FDI are quite sensitive to the exogeneity assumption, as we find much different estimates in many industrial sectors when we treat environmental regulations as endogenous. In addition, empirical results from our instrumenting regression equations provide insights not heretofore shown: corruption influences the supply of relevant public goods as well as the level of environmental regulation. These findings have clear new implications for policymakers, and provide avenues for future empirical and theoretical work on FDI, corruption, and the environment. 


\section{Acknowledgements}

The authors are extremely grateful to Arik Levinson for granting us access to the majority of the data used in this paper, as well as Michael Nelson for providing us with the corruption data. Lans Bovenberg and three anonymous referees provided very useful comments. The paper has also been improved by comments from Toke Aidt, Amy Ando, Bryan Caplan, Shelby Gerking, John Merrifield, Kamal Saggi, Scott Taylor, and participants at a ZEW workshop in Mannheim, Germany, the conference on 'The International Dimension of Environmental Policy' in Kerkrade, The Netherlands, the Southern Economic Association Annual Conference in Washington, DC, and at the Public Choice Society Meetings in San Antonio. The first author thanks SMU and the European Science Foundation (EURESCO) for travel funding. The usual disclaimers apply.

\section{Appendix A}

Following Grossman and Helpman (1994) and Bernheim and Whinston (1986), the characterization of the environmental policy selected by the dishonest bureaucrat is given by two necessary conditions: $V_{\psi}^{D B}(\psi)=0$; and $V_{\psi}^{i}(\psi)+$ $V_{\psi}^{D B}(\psi)=0$, for $i=E, W$. Combining these two conditions implies $V_{\psi}^{i}(\psi)=0$, which can be substituted into the first condition to yield the equilibrium characterization of the environmental policy set by a dishonest bureaucrat:

$$
\sum_{i=W, E} V_{\psi}^{i}(\psi)+\frac{\beta^{W} t \gamma}{\beta^{D B}} \frac{\partial k}{\partial \psi}=0
$$

The net effect of environmental policy on the gross welfare of the worker and environmental lobby groups equal $V_{\psi}^{W}(\psi)=\beta^{W}\left\{f_{\psi}+2 s f_{s k} f_{k \psi} /\left[f_{k k}+f_{s s} t^{2}(1-\gamma)^{2}+\right.\right.$ $\left.\left.2 f_{k s} t(1-\gamma)\right]\right\}$ and $V_{\psi}^{E}(\psi)=-\beta^{E} \beta^{W}<0$, respectively, where $f_{k s}=f_{s k}$ by Young's theorem. Substituting (2), $V_{\psi}^{W}$, and $V_{\psi}^{E}$ into (A.1) yields an equilibrium condition for policy $\tilde{\psi}$ set by the dishonest bureaucrat:

$$
f_{\psi}-\beta^{E}+\frac{2 s f_{k \psi} f_{s k}}{D}-\frac{t \gamma f_{k \psi}}{\beta^{D B} D}=0
$$

We cannot determine whether $\tilde{\psi} \gtreqless \hat{\psi}$, since the sum of the last two terms of (A.2) is ambiguous.

Assume for simplicity that all third-order derivatives can be approximated to zero (see Laffont and Tirole, 1998, p. 66). Total differentiation of (A.2) (after rearrangements) yields: 


$$
\frac{\partial \tilde{\psi}}{\partial \gamma}=\underbrace{t}_{\underline{M}}(\overbrace{\left(\beta^{E}-f_{\psi}\right)}^{2} \overbrace{2\left(f_{s s} t(1-\gamma)+f_{k s}\right)}^{?} \overbrace{-f_{k \psi}\left(2 k f_{s k}+1 / \beta^{D B}\right)}^{-})
$$

where $M<0$ is the second-order condition of (A.2) with respect to $\tilde{\psi}$ (required to be negative). $\partial \tilde{\psi} / \partial \gamma>0$ as long as $\beta^{E}>f_{\psi}$ and $f_{s s} t(1-\gamma)+f_{k s}<0$.

\section{Appendix B}

Table B1. First-stage regression results: Levinson index and government GSP

\begin{tabular}{|c|c|c|c|c|}
\hline \multirow[t]{2}{*}{ Variable } & \multicolumn{2}{|c|}{ Levinson index } & \multicolumn{2}{|c|}{ Government GSP } \\
\hline & $\begin{array}{l}\text { Models I } \\
\text { and II }\end{array}$ & $\begin{array}{l}\text { Models III } \\
\text { and IV }\end{array}$ & $\begin{array}{l}\text { Models I } \\
\text { and II }\end{array}$ & $\begin{array}{l}\text { Models III } \\
\text { and IV }\end{array}$ \\
\hline Corruption & $\begin{array}{l}0.02 \\
(1.82)\end{array}$ & & $\begin{array}{l}31.10 \\
(3.41)\end{array}$ & \\
\hline [Corruption] $^{2}$ & $\begin{array}{l}-1.14 \mathrm{E}-04 \\
(-1.30)\end{array}$ & & $\begin{array}{l}-0.33 \\
(-3.77)\end{array}$ & \\
\hline Corruption* & -0.02 & & -34.55 & \\
\hline Tax effort & $(-1.80)$ & & $(-3.77)$ & \\
\hline [Corruption* & $1.08 \mathrm{E}-04$ & & 0.33 & \\
\hline Tax effort $]^{2}$ & $(1.37)$ & & $(4.20)$ & \\
\hline $\begin{array}{l}\text { Legal services } \\
(\% \text { of GDP })\end{array}$ & $\begin{array}{l}-75.14 \\
(-1.27)\end{array}$ & $\begin{array}{l}-75.47 \\
(-1.33)\end{array}$ & $\begin{array}{l}1.55 \mathrm{E}+05 \\
(2.65)\end{array}$ & $\begin{array}{l}2.12 \mathrm{E}+05 \\
(3.66)\end{array}$ \\
\hline $\begin{array}{l}\text { [Legal services } \\
(\% \text { of } \mathrm{GDP})]^{2}\end{array}$ & $\begin{array}{l}4.54 \mathrm{E}+03 \\
(1.66)\end{array}$ & $\begin{array}{l}4.69 \mathrm{E}+03 \\
(1.78)\end{array}$ & $\begin{array}{l}-5.95 E+06 \\
(-2.21)\end{array}$ & $\begin{array}{l}-8.52 \mathrm{E}+06 \\
(-3.17)\end{array}$ \\
\hline $\begin{array}{l}\text { Non-military } \\
\text { government } \\
\text { employment }\end{array}$ & $\begin{array}{l}-3.35 \\
(-1.94)\end{array}$ & $\begin{array}{l}-2.73 \\
(-1.66)\end{array}$ & $\begin{array}{l}2.28 \mathrm{E}+04 \\
(13.36)\end{array}$ & $\begin{array}{l}2.55 E+04 \\
(15.16)\end{array}$ \\
\hline $\begin{array}{l}\text { [Non-military } \\
\text { government } \\
\text { employment] }\end{array}$ & $\begin{array}{l}1.82 \\
(2.21)\end{array}$ & $\begin{array}{l}1.67 \\
(2.07)\end{array}$ & $\begin{array}{l}2.25 \mathrm{E}+03 \\
(2.77)\end{array}$ & $\begin{array}{l}1.64 \mathrm{E}+03 \\
(1.98)\end{array}$ \\
\hline Per capita GSP & $\begin{array}{l}-0.04 \\
(-0.45)\end{array}$ & $\begin{array}{l}-0.02 \\
(-0.24)\end{array}$ & $\begin{array}{l}140.53 \\
(1.79)\end{array}$ & $\begin{array}{l}133.16 \\
(1.66)\end{array}$ \\
\hline$[\text { Per capita GSP }]^{2}$ & $\begin{array}{l}6.52 \mathrm{E}-04 \\
(0.30)\end{array}$ & $\begin{array}{l}1.43 \mathrm{E}-04 \\
(0.07)\end{array}$ & $\begin{array}{l}-2.26 \\
(-1.06)\end{array}$ & $\begin{array}{l}-2.32 \\
(-1.06)\end{array}$ \\
\hline Legal services* & -34.07 & -53.13 & $3.40 \mathrm{E}+04$ & $3.64 \mathrm{E}+04$ \\
\hline $\begin{array}{l}\text { Non-military } \\
\text { government } \\
\text { employment }\end{array}$ & $(-0.60)$ & $(-0.97)$ & $(0.61)$ & $(0.65)$ \\
\hline Highway miles & $\begin{array}{l}2.96 \mathrm{E}-04 \\
(1.17)\end{array}$ & $\begin{array}{l}0.04 \\
(1.27)\end{array}$ & $\begin{array}{l}55.18 \\
(2.19)\end{array}$ & $\begin{array}{l}61.16 \\
(2.37)\end{array}$ \\
\hline Population & $\begin{array}{l}-8.62 \mathrm{E}-05 \\
(-1.38)\end{array}$ & $\begin{array}{l}-0.06 \\
(-1.04)\end{array}$ & $\begin{array}{l}0.24 \\
(3.96)\end{array}$ & $\begin{array}{l}159.11 \\
(2.84)\end{array}$ \\
\hline Market proximity & $\begin{array}{l}6.25 \mathrm{E}-06 \\
(0.63)\end{array}$ & $\begin{array}{l}3.71 \mathrm{E}-06 \\
(0.44)\end{array}$ & $\begin{array}{l}0.06 \\
(6.53)\end{array}$ & $\begin{array}{l}0.06 \\
(7.39)\end{array}$ \\
\hline $\begin{array}{l}\text { Unemployment } \\
\text { rate }(\%)\end{array}$ & $\begin{array}{l}0.14 \\
(0.12)\end{array}$ & $\begin{array}{l}-0.02 \\
(-0.01)\end{array}$ & $\begin{array}{l}1.57 \mathrm{E}+03 \\
(1.37)\end{array}$ & $\begin{array}{l}1.19 \mathrm{E}+03 \\
(1.03)\end{array}$ \\
\hline
\end{tabular}




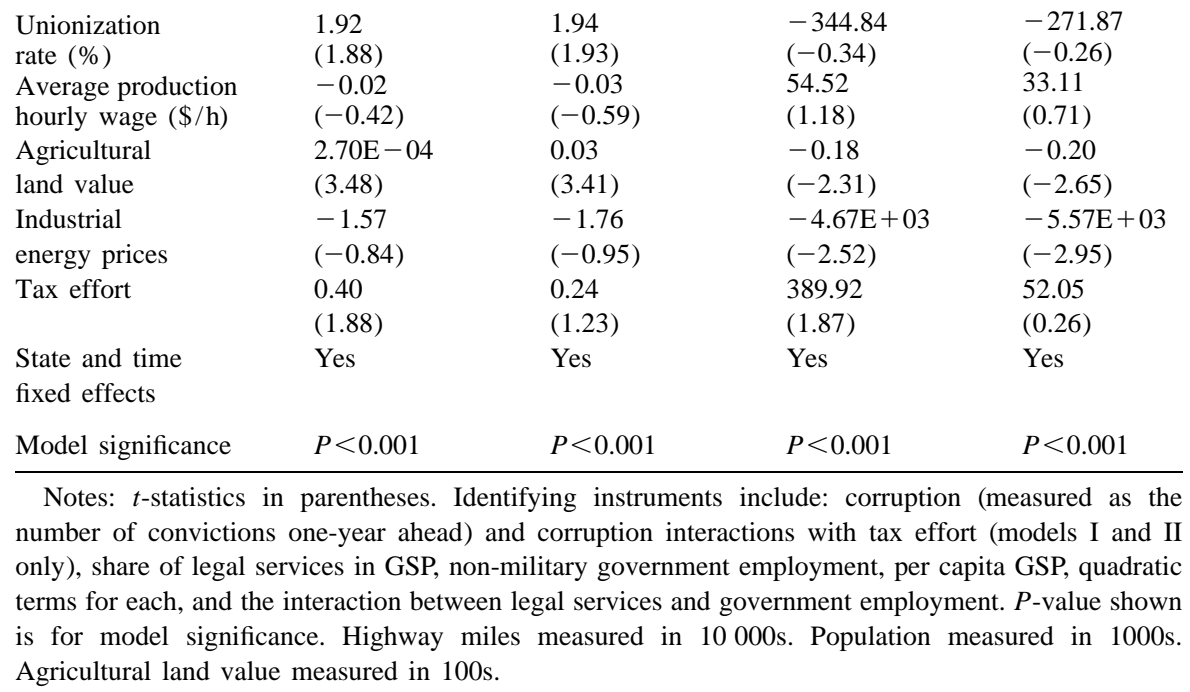

\section{References}

Basu, K., Bhattachaya, S., Mishra, A., 1992. Notes on bribery and the control of corruption. Journal of Public Economics 48, 349-359.

Bernheim, B.D., Whinston, M.D., 1986. Menu auctions, resource allocation, and economic influence. Quarterly Journal of Economics 101, 1-31.

Chandra, A., Thompson, E., 2000. Does public infrastructure affect economic activity? Evidence from the rural interstate highway system. Regional Science and Urban Economics 30, 457-490.

Damania, R., 2001. When the weak win: The role of investment in environmental lobbying. Journal of Environmental Economics and Management 42, 1-22.

Davidson, R., Mackinnon, S., 1993. Estimation and inference in econometrics, Oxford University Press, New York.

Devereux, M.P., Freeman, H., 1995. The impact of tax on foreign direct investment: Empirical evidence and the implication for tax integration schemes. International Tax and Public Finance 2, 85-106.

Durden, G.C., Shogren, J.F., Silberman, J.I., 1991. The effects of interest group pressure on coal strip-mining legislation. Social Science Quarterly 72, 239-250.

Eliste, P., Fredriksson, P.G., 2001. Environmental regulations, transfers, and trade: Theory and evidence, Journal of Environmental Economics and Management, forthcoming.

Eskeland, G.S., Harrison, A.E., 1997. Moving to greener pastures? Multinationals and the pollution haven hypothesis, World bank working paper \#1744, World bank, Washington, D.C.

Fredriksson, P.G., Gaston, N., 2000. Environmental governance in federal systems: The effects of capital competition and lobby groups. Economic Inquiry 38 (3), 501-514.

Fredriksson, P.G., Millimet, D.L., 2000. Bureaucratic Corruption and Environmental Policy: Theory and Evidence from the United States. Southern Methodist University, Mimeo.

Fisman, R., Gatti, R., 1999. Decentralization and Corruption: Cross-Country and Cross-State Evidence. Development Research Group, The World Bank, Mimeo.

Froot, K., 1993. Foreign Direct Investment. University of Chicago Press, Chicago.

Goel, R.K., Nelson, M.A., 1998. Corruption and government size: A disaggregated analysis. Public Choice 97, 107-120. 
Gordon, R.H., Bovenberg, A.L., 1996. Why is capital so immobile internationally? Possible explanations and implications for capital income taxation. American Economic Review 86, 1057-1075.

Greenstone, M., 1998. The Impacts of Environmental Regulations on Industrial Activity: Evidence from the 1970 and 1977 Clean Air Act Amendments and the Census of Manufactures. Working Paper \#408. Princeton University.

Grossman, G., Helpman, E., 1994. Protection for sale. American Economic Review 84, 833-850.

Helland, E., 1998. The enforcement of pollution control laws: Inspections, violations, and selfreporting. Review of Economics and Statistics 80 (1), 141-153.

Henderson, J.V., 1996. Effects of air quality regulation. American Economic Review 86, 789-813.

Hines, Jr. J., 1995. Forbidden Payment: Foreign Bribery and American Business After 1977. NBER Working Paper 5266. National Bureau of Economic Research, Cambridge.

Kahn, M.E., Matsusaka, J.G., 1997. Demand for environmental goods: Evidence from voting patterns on California initiatives. Journal of Law and Economics 40, 137-173.

Keller, W., Levinson, A., 1999. Environmental regulations and FDI inflows to US States: The potential for a 'race to the bottom' of environmental stringency, Review of Economics and Statistics, forthcoming.

Laffont, J.-J., Tirole, J., 1998. A Theory of Incentives in Procurement and Regulation. MIT Press, Cambridge.

Levinson, A., 2001. An industry-adjusted index of state environmental compliance costs. In: Metcalf, G., Carrero, C. (Eds.), Behavioral and Distributional Effects of Environmental Policy. University of Chicago Press, Chicago.

List, J.A., 2001. US county-level determinants of inbound Fdi: Evidence from a two-step modified count data model. International Journal of Industrial Organization 19 (6), 953-973.

List, J.A., Co, C.Y., 2000. The effects of environmental regulations on foreign direct investment. Journal of Environmental Economics and Management 40 (1), 1-20.

López, R., Mitra, S., 2000. Corruption, pollution, and the Kuznets environment curve. Journal of Environmental Economics and Management 40 (2), 137-150.

Mookherjee, D., Png, I.P.L., 1995. Corruptible law enforcers: How should they be compensated? Economic Journal 105, 145-159.

Morrison, C.J., Schwartz, A.E., 1996. State infrastructure and productivity performance. American Economic Review 86, 1095-1111.

Oates, W.E., Schwab, R.M., 1988. Economic competition among jurisdictions: Efficiency enhancing or distortion inducing? Journal of Public Economics 35 (3), 333-354.

Olson, M., 1965. The Logic of Collective Action. Harvard University Press, Cambridge, MA.

Shatz, H.J., Venables, A.J., 2000. The geography of international investment. In: Clark, G.L., Feldman, M., Gertler, M.S. (Eds.), The Oxford Handbook of Economic Geography. Oxford University Press, Oxford, Forthcoming.

Wei, S.J., 2000. How taxing is corruption on international investors? The Review of Economics and Statistics $82,1-11$.

Wheeler, D., Mody, A., 1992. International investment location decisions: The case of US firms. Journal of International Economics 33, 57-76. 